\title{
A DÉLVIDÉKI MAGYAR TUDÁSTÁR LÉTREHOZÁSA
}

\author{
HAJNAL JENÖ \\ Magyar Nemzeti Tanács (Vajdaság), elnök
}

\begin{abstract}
ABSZTRAKT
A nemzeti kulturális örökség részeként a délvidéki/vajdasági magyarság szellemi örökségének digitalizálása alapvető fontosságú közösségi érdek, amelynek megkerülhetetlen intézményei a magyar érdekeltségú közkönyvtárak. Mindez megköveteli a kulturális értékek - különösen a szellemi örökség - felé fordulást: a szülőföld, a táj magyar történetének virtuális felfedezését, és az elmúlt sok száz esztendő műveltségi eseményeire való fényderítést. Életünknek és szellemi alakulásunknak ugyanis olyan korszakába léptünk, amely a teljességet igényli, s nem lehet meg sem annak az örökségnek a termékeny felszívása nélkül, amelyet kisebbségi létünk csaknem egy évszázada halmozott fel, sem a tájainkkal kapcsolatban álló több mint ezeréves múlt tudatosítása nélkül. A digitalizálási tevékenység összehangolása és nyilvántartása elengedhetetlen a költségek kímélése, a munka hatékonyságának növelése, a digitalizálás minőségének biztosítása és a felhasználó tájékoztatása szempontjából. Átfogó célunk, hogy közgyüjteményeink, mindenekelőtt könyvtáraink váljanak alkalmassá az információs társadalom és a digitális korszak kihívásainak kezelésére, és feleljenek meg az új korszak követelményeinek. Közvetítésükkel digitális formában is legyen elérhető a vajdasági magyar nemzeti közösség szellemi öröksége, amely így szabadon, hozzáférhető módon segitheti a kutatást, a képzést, az önképzést, és megfelel a nemzeti kultúra megőrzésére irányuló Kárpát-medencei célkitűzéseknek is. A cél: egy sokszereplős, változékony, de stabil alapokon nyugvó tudástár felépítése, amelynek tartópillérei a vajdasági magyar közgyújtemények adatbázisai lehetnek azok folyamatos fejlesztésével, integrációjával és nemzetközivé tételével.
\end{abstract}

Talán még sosem éreztem ennyire találónak a Magyar Tudomány Ünnepének mottóját kisebbségi léthelyzetünkre vonatkoztatva, mint épp az ideiét, mely szerint: „A tudomány evolúciója: a valós és a virtuális világok”. Mi ennek a „valós és virtuális világoknak” az öszszetettségét lassacskán már egy évszázada úgy éljük meg, mint ahogyan azt Szenteleky Kornél, a vajdasági magyar irodalom atyja a Magyar gyarmatok címú, 1927 augusztusában megjelent írásában megfogalmazta: „minden magyar népdarab önálló szellemi életre van utalva, és ebben az életre kelésben nincs karon fogó szüléje, segítőtársa vagy gyámolítója, csak önmaga". ${ }^{1}$ Ez volt az a történelmi pillanat, amikor tudatos belátását tapasztaljuk annak, hogy Trianon után „valós” önálló szellemi életre van kényszerítve az utódállamokban születő magyar kultúra, mert „csak a jelek valamilyen rendszerére lefordított dolgok válhatnak az emlékezet tulajdonává”. ${ }^{2}$

Nevezhetnénk ezt a pillanatot a vajdasági magyar kultúra megszületésének is, ha megfeledkezhetnénk arról a kényszerhelyzetről, amelyben a kisebbségek kulturális azonosságát a ,virtualitás”, az elrejtettség jellemzi, vagyis nemzetállami keretek között „azoknak a kisebbségi azonossági alakzatoknak a neve, amelyek nem kapcsolódnak a nemzetállamhoz, 
nem jelennek meg az állam elnevezésében, láthatatlanok a nyilvános szférában”. ${ }^{3}$ Ahhoz ugyanis, hogy egy kisebbség önazonossága megnyilvánulhasson, szembe kell néznie azzal a kihívással, hogy milyen mértékben lehetséges kisebbségi azonosságainak kommunikációja, és hogy miben határozhatja meg identitásának magvát.

Ez olyan stratégiai célkitǔzés, mely szerint a szélesen értelmezett kultúra a vajdasági magyar nemzeti közösség fejlesztésének egyik nagyon fontos eszköze, hiszen a kultúrának kulcsszerepe lehet a társadalmi igazságosság megteremtésében, a szociális integrációban; de választ adhat a kor legfontosabb társadalmi problémáinak - akár az identitáskeresésnek - megoldására is. Éppen ezért tartottuk a Vajdaságban lényegesnek a kultúra egészének stratégiai szintű felértékelését és fejlesztésének kidolgozását. Ehhez legfontosabb eszközünk a nemzeti tanácsokról, továbbá a kultúráról szóló törvény volt, valamint azok a tartományi és uniós fejlesztési tervek, amelyek szerint a kulturális fejlesztés a területfejlesztés elengedhetetlen része. Ezen a területen tevékenységünk tehát elsősorban afelé fordult, hogy a kultúra területén feladatot vállalók között kialakuljon és erősödjön a közös tervezés és cselekvés igénye.

Ezért látom a nemzeti kulturális örökség részeként a délvidéki/vajdasági magyarság szellemi örökségének digitalizálását alapvető fontosságú közösségi érdeknek, amelynek megkerülhetetlen intézményei a magyar érdekeltségú közkönyvtárak.

A „könyvtári valóság” ugyanis az, hogy a Vajdaságban túlnyomórészt magyar nyelvű könyvtári dokumentumokkal rendelkező könyvtárakról, kizárólag magyar kisebbségi könyvtárügyről nem beszélhetünk, hiszen a könyvtárak egységes rendszert alkotnak, amelynek élén a Szerb Matica Könyvtára mint nemzeti könyvtár áll, majd a törzskönyvtárak és a közmúvelődési könyvtárak következnek.

Ebben a jelenleg igen laza hálózatban a közmúvelődési könyvtárak száma 44, vagyis minden községben (kommunában) egy-egy ilyen intézmény múködik összesen 196 könyvtári részleggel. Közülük 34-ben összesen 969074 magyar nyelvű könyv található (ez a teljes könyvállománynak kb. a 21,40\%-a). A legtöbb magyar nyelvú könyv Szabadkán (102 489), Topolyán (90 290), Zomborban (65 713), Zentán (45 413), Magyarkanizsán (44 332), Óbecsén (38 611), Nagykikindán (29 303), Adán (27 853), Újvidéken (23 380), Kishegyesen (20 764) és Temerinben (20 000) található. ${ }^{4}$

A vajdasági könyvtári életben sajátos szerepet tölt be a Kapocs Könyvtári Csoport mint hivatalosan nem bejegyzett, azaz „virtuális”, de mégis nagyon is valóságos érdekeket képviselő szervezet. A könyvtárcsoport azt a feladatot vállalta fel ugyanis, hogy ellássa a térségünkben működő magyar könyvtárak együttmúködésének szervezését, hogy gondoskodjék a helyi könyvtárügyet építő szolgáltatások és képzések megszervezéséről, illetve egyéb könyvtári és közművelődési szolgáltatásokról. Napjainkig már sikerült leraknia egy olyan múködő információs-módszertani könyvtári központ alapjait, amelynek elsődleges feladata lett a vajdasági magyarság anyanyelvú információellátásának segítése és a közművelődési könyvtárak fejlesztése.

Az utóbbi évek arról tanúskodnak, hogy magyar érdekeltségű könyvtáraink régi funkciójukat jelentősen kibővítve az információs társadalom fontos közintézményeivé 
váltak. A közösségi élet perifériájáról mindinkább kisebbségi létünk centrumába kerülnek, azaz többszörösen is nyitottá válnak, vagyis: az új kihívások kipróbálásának színterei, a kibővülő ismeretszerzési lehetőségek megismerésének és begyakorlásának helyei. Ennek esélyeit erősítették azok az anyaországi fejlesztések is, amelyekben mind fontosabb szerephez jutott a délvidéki korszerű közművelődési tevékenységekhez kapcsolódó informatikai rendszerek kiépítése. A számítógépek segítségével pedig a könyvtárnak kiemelkedően fontos szerepe lett abban, hogy az informatizálódó társadalmon belül - határokon átnyúlva - a Kárpát-medence valamennyi magyar közössége informált társadalommá, sốt tudástársadalommá váljon, mégpedig saját anyanyelvén.

Mindez azonban megköveteli a kulturális értékek - különösen a szellemi örökség felé fordulást: a szülőföld, a táj magyar történetének virtuális felfedezését, és az elmúlt sok száz esztendő műveltségi eseményeinek megismerését. Életünknek és szellemi alakulásunknak ugyanis olyan korszakába léptünk, amely a teljességet igényli, s nem lehet meg sem annak az örökségnek a termékeny felszívása nélkül, amelyet kisebbségi létünk csaknem egy évszázada halmozott fel, sem a tájainkkal kapcsolatban álló több mint ezeréves múlt tudatosítása nélkül. A digitalizálási tevékenység összehangolása és nyilvántartása elengedhetetlen a költségek kímélése, a munka hatékonyságának növelése, a digitalizálás minőségének biztosítása és a felhasználó tájékoztatása szempontjából. Átfogó célunk, hogy közgyüjteményeink, mindenekelőtt könyvtáraink váljanak alkalmassá az információs társadalom és a digitális korszak kihívásainak kezelésére, és feleljenek meg az új korszak követelményeinek. Közvetítésükkel digitális formában is legyen elérhető a vajdasági magyar nemzeti közösség szellemi öröksége, amely így szabadon, hozzáférhető módon segítheti a kutatást, a képzést, az önképzést, és megfelel a nemzeti kultúra megőrzésére irányuló Kárpát-medencei célkitűzéseknek is. A cél: egy sokszereplős, változékony, de stabil alapokon nyugvó tudástár felépítése, amelynek tartópillérei a vajdasági magyar közgyújtemények adatbázisai lehetnek azok folyamatos fejlesztésével, integrációjával és nemzetközivé tételével.

2011 novemberében készült el a vajdasági magyarság 2012-2018 közötti kulturális stratégiája. Egy olyan dokumentum, amely az intézményes működés alapfeltétele, és amely közösségünk kulturális küldetésének hatékony megvalósítását tűzte ki célul, stratégiai feladatát pedig egy olyan nyitott kultúrának építésében látja, amely a külső hatásokra fogékony, azokat folyamatosan földolgozni és integrálni képes, amely önazonosságát nem változatlanságában őrzi, hanem tudatos megújulásában és szintézisében munkálja ki. Ezért lett a kulturális stratégia alapvető célja a vajdasági magyar kulturális háló kialakítása és működtetése, amelynek „eredményeképpen a hivatásos intézmények és az amatőr mûvelődési élet alakítói az örökségvédelem és értékteremtés minden területén a kulturális tér egyenletes fejlesztését valósíthatják meg". ${ }^{5}$

A stratégiai célok megvalósításában fontos menedzseri feladatok hárulnak a zentai székhelyű Vajdasági Magyar Művelődési Intézetre is, hogy a rendelkezésére álló intézményi eszköztárral (tervezés, szervezés, koordinálás, infrastruktúra, szakembergárda stb.) minél eredményesebbé tegye a vajdasági magyar nemzeti közösség kulturális küldetését. 
Egyébként a tíz évvel ezelőtt létrehozott intézményben az elmúlt időszakban folyamatos, szerteágazó és az intézmény alaptevékenységeit (közgyűjteményi, közművelődési és tudományos-kutatói) egyensúlyban tartó munka folyt, amelynek eredményeképp létrejött és napról napra bővül a vajdasági magyar könyv-, lap-, folyóirat-, kép-, mozgóképés levéltári gyűjtemény, az ún. dokumentációs központ, információs adatbankja pedig országos hírűvé vált. A társadalomtudományi kutatómunka, igaz, egyelőre csak külső munkatársakkal, de kézzelfogható eredményekkel büszkélkedhet (ezek közül kiemelkedik a bibliográfiák készítése, a vajdasági magyarság kronológiája, az 1941 és 1948 közötti időszakra vonatkozó levéltári kutatások, valamint visszaemlékezések rögzítése és írásos formában történő lejegyzése). Az intézet további feladatai közé tartozik a könyvtárosok, a közművelődési szakemberek, az amatőr színjátszók és rendezôk szakmai továbbképzésének megszervezése; a Vajdasági Magyar Művelődési Portál és a Vajdasági Magyar Digitális Adattár múködtetése; továbbá az intézet „,vonzáskörzetébe” tartozó területeken magyarországi, Kárpát-medencei és nemzetközi kapcsolatok ápolása.

A 2012 és 2018 közötti időszakban a Magyar Nemzeti Tanács által kiemelt jelentőségű közgyűjtemények egyik legjelentősebb projektje a vajdasági közgyűjteményekben őrzött magyar vonatkozású műtárgyak és a szellemi örökség megőrzése és gyarapítása. Mindez sürgős szoftverfejlesztéseket és a közgyüjteményi digitális objektumok módszertani kezelésének a mielőbbi kidolgozását igényli a Vajdasági Magyar Művelődési Intézetnek mint közgyűjteményi regionális központnak, továbbá az adai, magyarkanizsai, óbecsei, szabadkai, topolyai és zentai kompetenciaközpontoknak a közvetítésével: (1) Adán a Szarvas Gábor Könyvtárban; (2) Magyarkanizsán a József Attila Könyvtárban; (3) Óbecsén a Népkönyvtárban és a Városi Múzeumban; (4) Szabadkán a Városi Könyvtárban, a Városi Múzeumban és a Történelmi Levéltárban; (5) Topolyán a Népkönyvtárban és a Városi Múzeumban; továbbá (6) Zentán a Városi Könyvtárban, a Városi Múzeum és Képtárban, valamint a Történelmi Levéltárban.

Most folyik - alkalmazva a digitalizálásra, a feltárásra és a megőrzésre vonatkozó ajánlásokat és szabványokat ${ }^{6}$ - a digitális tartalmak begyüjtésének, feldolgozásának és hosszú távú megőrzésének szervezett kialakítása. Hagyományaink főbb digitalizálási területei: a népi műveltség, a történelmi hagyományok, a szépirodalom, az épített és képzőművészeti örökség (a román, a gót, a reneszánsz, a barokk és klasszicizmus építészete és festészete, a történelmi festészet, a szecesszió és az impresszionizmus ugyancsak festészeti és építészeti hagyománya, a két világháború közötti festészet és szobrászat, a múvésztelepi alkotómúhelyek értékteremtése), a zenei hagyományok (különösen a dalkultúra), a filmgyártás emlékei, a színházi élet, a tudományosság szöveges emlékei (történetírás, néprajz, szociológia, filozófia, földrajz, gazdag pedagógiai tevékenység). ${ }^{7}$ A vajdasági magyarságra vonatkozó vagy ott publikált dokumentumok digitalizálandó múfajai: könyvek, hírlapok és folyóiratok, továbbá kisnyomtatványok, plakátok, térképek, statisztikai adatbázisok, néprajzi kéziratos szakértői anyagok, személyi kéziratos hagyatékok, intézményi levéltári anyagok, archiválható audiovizuális anyagok stb. 
A digitalizálás alapfeltétele a hagyományos leíró adatok (bibliográfiai leírások) szabványos rögzítése digitális formában (retrospektív konverzió), valamint a speciális dokumentumok (kéziratok, kották, térképek, régi könyvek stb.) leíró adatainak szabványos rögzítése úgyszintén digitális formában: bibliográfiák (repertóriumok, cikk-, életmú-, tematikus bibliográfiák); sajtótörténet; egyes szakterületek és müvészeti ágak szellemi örökeségének digitalizálása: Kismonográfiák (1976-1993), Gemma Könyvek (1976-), Forum Kiskönyvtár (1979-1990), legjelentősebb íróink életmúsorozata (1983-), Jugoszláviai Magyar Regénykönyvtár (1981-1989), egyéb könyvsorozatok: Jugoszláviai Magyar Könyvtár (1932-34), Kalangya Könyvtár (1933-1934), Kisebbségi Könyvtár (1937-1938), Híd Könyvtár (1939-1940), Színpadunk (1945-1951), Jugoszláviai Magyar Írók (1946-1949), Jugoszláviai Magyar Irodalom (1956), Zentai Füzetek (1960-), Symposion Könyvek (1963-1990), Zentai Monográfia Füzetek (1964-), Hitélet Kiskönyvtára (1967-1980), Életjel Miniatűrök (1968-1995), Temerini Füzetek (1969), Életjel Könyvek (1973-), a Hungarológiai Intézetnek, illetve A Magyar Nyelv, Irodalom és Hungarológiai Kutatások Intézetének könyvsorozatokon kívül megjelent egyéb, több mint harminc kiadványa (1973-), a Vajdaság Helységeinek Földrajzi Nevei 1-14. (19751989) [Topolya, Szabadka, Kishegyes, Ada, Zenta, Szenttamás, Temerin, Magyarkanizsa, Óbecse, Gombos, Kúla, Bezdán, Doroszló és környéke földrajzi neveinek adattára] címú kiadványsorozat, nyelvatlaszok 1-3. [Penavin Olga, Matijevics Lajos / A jugoszláviai székelytelepek nyelvatlasza (1978), Penavin Olga / Horvátországi (szlavóniai) magyar nyelvjárási atlasz (1984), Penavin Olga / Bácskai magyar nyelvjárási atlasz (1988)], Symposion-lemezek (1979), az Irodalomtudományi Dolgozatok 1-3. (1980-1992) címú könyvsorozat, az Értekezések, Monográfiák 1-24. (1982-1991) [néprajzi, délszláv-magyar kapcsolat-, múvelődés-, színház-, sajtó- és irodalomtörténeti, valamint nyelvészeti tárgyú szerzői munkákat, illetve szövegválogatásokat tartalmazó] könyvsorozat, a Jugoszláviai Magyar Népzene Tára 1-4. (1982-1990) [Gombos és Doroszló népzenéje, Az al-dunai székelyek népdalai, A drávaszögi magyarok dalai, A szlavóniai szigetmagyarság népdalai] címú könyvsorozat, Nyelvművelő Füzetek 1-4. (1984-1993) című könyvsorozat, Topolyai Füzetek (1985-1990), Új Symposion Füzetek (1988-89), a Jugoszláviai Magyar Nyelv Rétegei 1-2. (1991) [helyi vonatkozású (nyelvjárási tárgyú, szakszókincset bemutató) kiadványok] című könyvsorozat, a Jugoszláviai Magyar Művelődési Társaság Kiskönyvtára (1992-); az 1940-es évek tragikus eseményeiröl szóló könyvek elektronikus feldolgozása; folyóiratok, évkönyvek: Kalangya (1932-1944), Hétről-Hétre (1934-1935), Híd (1934-1940, 1945-), Üzenet (1971-), Létünk (1972-), Új Symposion (1964-), Tanulmányok (1969-), Hungarológia Intézet Tudományos Közleményei (1969-1976), Hungarológiai Közlemények (1976-); napi- és hetilapok: Bácsmegyei Napló / Napló (1903-1944), Hírlap (1921-1929), Délbácska / Reggeli Újság (1920-1944), Torontál (1892-1941), Sombori Újság (1925-1931), Új Hírek (1930-1941), Szabad Vajdaság / Magyar Szó (1944-), 7 Nap (1946-); lexikonok: Kalapis Zoltán / Életrajzi kalauz. Ezer magyar biográfia a délszláv országokból. I-III. (2002-2003), Gulyás Gizella / Kortárs vajdasági magyar művészek lexikona (2003), Balázs-Arth Valéria / Délvidéki Magyar 
Képzőművészeti Lexikon (2007), Gerold László / Jugoszláviai magyar irodalmi lexikon. 1918-2000 (2001), Hódi Sándor, Hódi Éva / Vajdasági magyar ki kicsoda 2010; statisztikák: Sebők László / A Vajdaság nemzeti és felekezeti statisztikája településenként (1850, 1863-2002); térképek: vajdasági többnyelvű útvonalkereső térkép elkészíttetése, a vajdasági városok térképei, Kocsis Károly / a Vajdaság etnikai viszonyainak változása, Délvidék, Jugoszlávia, a Vajdaság közigazgatási viszonyainak változása; kronológiák: Mák Ferenc / Magyarok a Vajdaságban (1918-1944), Vékás János / Magyarok a Vajdaságban (1944-1954), Vékás János / Magyarok a Vajdaságban (1955-1964), Vékás János / Magyarok a Vajdaságban (1965-1994); fotóarchivum: események, rendezvények, régi képes levelezőlapok, egyéni gyűjtemények stb. elektronikus tárolása; hangtár: a Vajdasági Magyar Népzenei Archívum teljes anyagának digitális rögzítése és leltárba vétele, Bodor Anikó, Burány Béla, Borús Rózsa, Király Ernő, Tripolsky Géza néprajzi hagyatékának digitalizálása, az Újvidéki és a Szabadkai Rádió hangzó dokumentumainak archiválása; mozgóképarchivum: a vajdasági magyar kultúra mozgóképeken őrzött örökségének (film, színház, televízió, rendezvények, események stb.) leltárba vétele és digitalizálása; az eleve digitális formában keletkęett objektumok kęelése.

A digitalizálás következő lépése magának a tudástárnak a felépítése lesz. Ennek alappillérei a regionális és a tizenkét kompetenciaközpont adatbázisai lesznek.

„A kultúra nem tudás, nem múvészi produkció, hanem valami életet szabályozó elv, amely egy embercsoport minden tagjának belső mágnese, irányítója" ${ }^{\text {" }}$ - vallotta Németh László már 1928-ban. A felvetett gondolatok fényében még inkább úgy látszik, hogy nagymértékben tőlünk, könyvtárainktól, intézeteinktől is függ, hogy tájainkon és a Kárpát-medencében is képes lesz-e még jobban megerősödni ez a „belső mágnes”, kohéziós erő, „életet szabályozó elv”, amelynek segítségével még mindig átörökíthetők a belsővé váló magatartásnormák, a példák összessége, mégpedig a legkevésbé közvetlen, de épp ezért a leginkább hatékony módon.

\section{Irodalom}

${ }^{1}$ SZENTELEKY Kornél: Új életformák felé: egybegyüjtött tanulmányok, kritikák, cikkek (1922-1930). Újvidék, Forum Könyvkiadó, 1999. 156. p.

${ }^{2}$ LOTMAN, Jurij: Szöveg-modell-típus. Budapest, Gondolat Kiadó, 1973. 276. p.

${ }^{3}$ LOSONCZ Alpár: Európa-dimenziók: kultúra, kontextus, kisebbség - fenomenológiai távlatok. Újvidék, Forum Könyvkiadó, 2002. 249. p.

${ }^{4}$ ČAMBER, Silvija: Analiza rada narodnih biblioteka u Vojvodini za 2014. godinu [A vajdasági közkönyvtárak 2014. évi tevékenységének elemzése]. Novi Sad, Biblioteka Matice srpske, 2015. 3-4., 16-17. p.

${ }^{5}$ Vajdasági magyar kulturális stratégia 2012-2018. Szabadka, Magyar Nemzeti Tanács Közigazgatási Hivatala, 2011. 4. p.

${ }^{6}$ NOKI Plusz Bizottság: Országos Könyvtári Digitalizálási Terv (2007-2013). Forrás: http:/ [-] ki.oszk.hu/content/orsz-gos-k-nyvt-ri-digitaliz-l-si-terv-2007-2013-national-digitisation-[-] plan-libraries-2007-2 [2016. január 8.] 
${ }^{7}$ Vö. BORI Imre: A hagyományok feltárásának feladatáról. In: Uő: Identitáskeresőben: mûvelődéstörténeti tanulmányok - művelődéspolitikai cikkek. Újvidék, Forum Könyvkiadó, 2000. 144-145. p.

${ }^{8}$ NÉMETH László: Molnár Albert zsoltárai és ritmikájuk. In: Uő.: Az én katedrám: tanulmányok. Budapest, Magvető és Szépirodalmi Könyvkiadó, 1975. 98. p.

Hajnal Jenő magyartanár, könyvtáros, kulturális mediátor, a nyelvtudományok magisztere, tudományos kutató, a Vajdasági Magyar Nemzeti Tanács elnöke. 1954-ben született Bácsgyulafalván. Dolgozott középiskolai tanárként, rádióriporterként, újságíróként, fordítóként, a zentai közművelődési központ (1988-2006) és a Vajdasági Magyar Mûvelődési Intézet (2006-2014) igazgatójaként. A Magyar Tudományos Akadémia külső köztestületi tagja (2004-). 